\title{
TWENTY-FIVE YEARS OF ECOLOGICAL TRUTH
}

\section{DVADESET PET GODINA EKOLOŠKE ISTINE}

\author{
Petar Paunovic
}

\section{RAJAC SCHOOL OF HEALTH, VUKA KARADZICA 49, 19314 RAJAC, NEGOTIN, SERBIA}

\begin{abstract}
On the occasion of June 5, the World Environment Day (WED), in 1993, the first ecological symposium "Our Ecological Truth" was organized in Zajecar. The main goal of this meeting is conceived as the possibility to start activities and discussions on ecology and ecological problems in the conditions of war and social crisis, poverty and scarcity of every kind. Soon after its establishment, "Our Ecological Truth" slowly transformed into the ecological movement of the Timocka Krajina. It has become a major driver of environmental activities in the political, scientific, professional and social level. In the last two and a half decades, "Ecological Truth" has evolved and gone through various phases: from a national meeting to an international conference. Ecological Truth has its own mission, which meets every year. Its strength is reflected in its successful living and being held every year in the 21st century. One of the basic tasks of the author of this lecture is an analysis of the achieved results in the period from 1993 to 2017.

Keywords: WED, 1993., conference, ecology, twenty-five years, 2017.
\end{abstract}

Sažetak: $\quad$ Povodom 5. juna, Svetskog dana zaštite životne sredine, u Zaječaru je 1993. godine organizovan prvi ekološki simpozijum "Naša ekološka istina". Glavni cilj ovog sastanka bio je zamišljen kao mogućnost započinjanja aktivnosti i diskusija o ekologiji i ekološkim problemima u uslovima rata i društvene krize, siromaštva i oskudice svake vrste. Ubrzo nakon osnivanja, "Naša ekološka istina" se polako transformisala u ekološki pokret Timočke Krajine. On je postao glavni pokretač aktivnosti na zaštiti životne sredine na političkom, naučnom, stručnom i društvenom nivou. Za poslednje dve i po decenije, "Ekološka istina" je evoluirala i prošla kroz razne faze: od nacionalnog skupa do međunarodne konferencije. Ekološka istina ima svoju misiju, koja se ispunjava svake godine. Njena snaga se ogleda u njenom uspešnom postojanju i u tome da se održava svake godine u 21. veku. Jedan od osnovnih zadataka autora ovog predavanja je analiza postignutih rezultata u periodu od 1993. do 2017. godine.

Ključne reči: $\quad$ 1993., konferencija, ekologija, dvadeset pet godina, 2017.

\section{INTRODUCTION}

Preparing for this lecture, the authors were considering whether the twenty-five years of the continuous duration of the "Ecological Truth" was a long enough period to look back and find out which one of the benefits of such a scientific conference of international reputation was used, and how far the development of ecological idea has gone and which way it should go further. Furthermore, is something like that so necessary at all today, when the "Ecological Truth" continues its way on, as it was before? For the first time, such a look back was made after ten such conferences [1]. It was quite a lot of work that needed to be done: regarding the definition of ecology and harmonization of ecological terms and concepts, expertmethodological and essential approach to ecology as a science and the possibilities of its use in everyday life. Ecology is a young science, with an interesting history. The term "ecology" was first used by Ernst Hekel, a follower of the great Darwin, defining it through the relations with the surrounding environment including, in the broadest sense of the word, all the existential relationships of living beings and the environment [2]. Ecology is the science of life, which provides the scientific basis for the protection of nature. The term human ecology is also used, most often when it comes to ecological analyses and activities that go hand in hand with the leading political elites and modern economies and their institutions, in order to 
maintain production that is harmful to the environment and when it wants to maintain an environmentally harmful order - homo tehnicusa [3].

The definition of ecology and functioning of the ecosystem is also found in the "Framework of Life" [4] of our scientist Sinisa Stankovic, born in Zajecar.

\section{WHAT PRECEDED ECOLOGICAL TRUTH? Hygiene - medical ecology}

In the sixties of the last century, at the time when the development of industrialization took place, it was necessary, within the framework of the program of "reconstruction and development of socialism" in Yugoslavia, to build factories, restore mines, build electric power plants, railways and roads in the Timok region, to restore the economy as a whole, and to increase the production especially in Bor and Majdanpek. We will also mention here the impacts on the nature, life and health of the population that were created by the construction of the HPP "Djerdap I", where the interventions on the Danube and the riverbank were such that they significantly influenced the flora, fauna and population both on our and Romania's side. At that time, the ecological fate of this area was altered.

At that time, the Institute of Hygiene in Zajecar was founded with a purpose to monitor the impact of the environment on human health, at first, in industrial plants, and later to spread out, to control the impact of air, noise, lighting and temperature in the manufacturing plants on the health of workers, and later the quality of toxic gases and wastewater from industrial plants and other harmful effects on the environment. Doctors were sent to specialize in hygiene, a medical science with attributes of medical ecology. The institute was equipped with adequate equipment, it employed technicians, chemists and toxicologists and gave the first results regarding the state of the environment in the Timok Krajina region.

Bor mine - the biggest polluter of the environment in Yugoslavia

The results of laboratory investigations of the quality of air, watercourses and soil clearly show that in the seventies, Bor and its surroundings were the most polluted and most devastated areas in Yugoslavia. The Timok river became a collector of industrial waters of the Bor copper mine, in which every form of life ceased to exist. It should be said that the Timok river was at the same time a collector of wastewaters from the industry and cities of Knjazevac, Zajecar and Boljevac. During the spring floods, the Timok was poisoned by poisonous pyrites and it permanently destroyed fertile soil from the Vrazogrnac river to its confluence in the Danube from year to year. The peasants from Brusnik, Bracevac, Tamnica, Rajac, Rogljevo and Kovilovo were left without more than a thousand hectares of fertile land. The peasants from the Bulgarian villages, downstream of Bregovo, suffered damage too.

As far as the Bor mine is concerned, in all the reports and analyses, which always had the significance of a political message, there were always just praises. No harmful impacts on the environment, nor a proposal for measures to stop further degradation of nature and sanitize the consequences. A similar situation was in Majdanpek. The Country needed copper and gold. The political and economic elites in Yugoslavia were satisfied.

Ecological incidents, rebellions and meetings

The peasants, who were partly miners in nearby mines and factories in the cities nearby, weren't satisfied with the progress of industry and mining in the Timok region. After World War I, the development of mining in this region caused the degradation of the land and the great dissatisfaction of the population due to such destruction of nature and fertile soil. It was the reason for the peasants' rebellions in the surrounding of Bor, below Rtanj and in the vicinity of Vine. Thus, the "Bulletin of the Moravian Banovina Chamber of Commerce" published in the number 3 , January 1,1939 , the following article: "The coal mine Rtanj discharges its coal mine black water in the Mirovstica River, and further into the Black River. From polluted water, the fish died and the animals were killed, especially during drought. Taking this into account, our chamber has threatened the Ministry of Forests, Mines and Banks, asking to protect the interests of agriculture in this region [5]".

Much worse situation was in the vicinity of Bor and along the Borska river and in the vicinity of other mining and industrial plants between the two wars. On May 7, 1935, the following was written about the rebellion of peasants from the Bor region in the Letopis of Bor Parrohi and the Church: „On that day, 
peasants from Bor, Slatina, Krivelj, Ostrelj, Brestovac, Bucje, Metovnica and Bela Reka, with skillful concentration and sudden attack, stopped the operation of the copper smelter in the Bor mine after they had beaten some of the personnel in the smelter and banned the work. They were desperate and forced to do it because of the destructive effect of poisonous smoke from the smelter on their crops, soil and cattle. From that day till the 31st of May the smelter did not work, so there was the grace to watch the plants develop and the fields covered by greenery. In the absence of toxic smoke from the smelter, farmers' crops began to progress and even some birds that had not existed before appeared, and with their tweetment, gave life and joy to nature. But on June 1, the Smelter started working again and the smoke from it began to cover, with the fading death, trees, grass, fields, and even the birds under its influence were expelled. - Ah! When will the poisonous effect of this smoke finaly disappear? When the righteous desire of the peasant will be fulfilled, that the smoke does not destroy the soil, his cattle and his health! [6]".

After the demolition of a dam on the lake where waste waters and pyrite from the mine in Majdanpek were collected, the village of Debeli Lug and the riverbank area were flooded to the mouth of the river Pek into the Danube. Residential buildings, stables and yards in Debeli Lug were flooded with toxic wastewater and pyrite, arable land was endangered and living organisms were destroyed in the water of the Pek River and the Danube.

In the mid-seventies of the 20th century, the communal environment of Zajecar was burdened with industrial pollution from a glass factory, from steam locomotives at the railway station and individual fireplaces. The public was especially harassed by the pollution from industrial plants in the glass factory. In those years, the measurement of air pollution in the communal environment started. After three years of measurement, it was shown that the air was polluted by the contents of the vapor from the glass factory, and it was ordered that measures be taken to reduce the pollution. There were suggestions that the railway station should be moved to another location, thus reducing air pollution by smoke from steam locomotives. This did not happen because these were soon replaced by electric motor trains. In Bor, the situation was even worse, because the level of pollution in the municipal environment of industrial gases was above the maximum concentration allowed daily.

The situation did not improve much, so the population's dissatisfaction led to an ecological meeting in the center of Zajecar in the early 1990s, attended by about 3,000 people. A few days later an ecological meeting was organized in Bor, too [7].

Figure 1 Ecological meetings in Zajecar and Bor Slika 1 Ekološki skupovi u Zaječaru i Boru

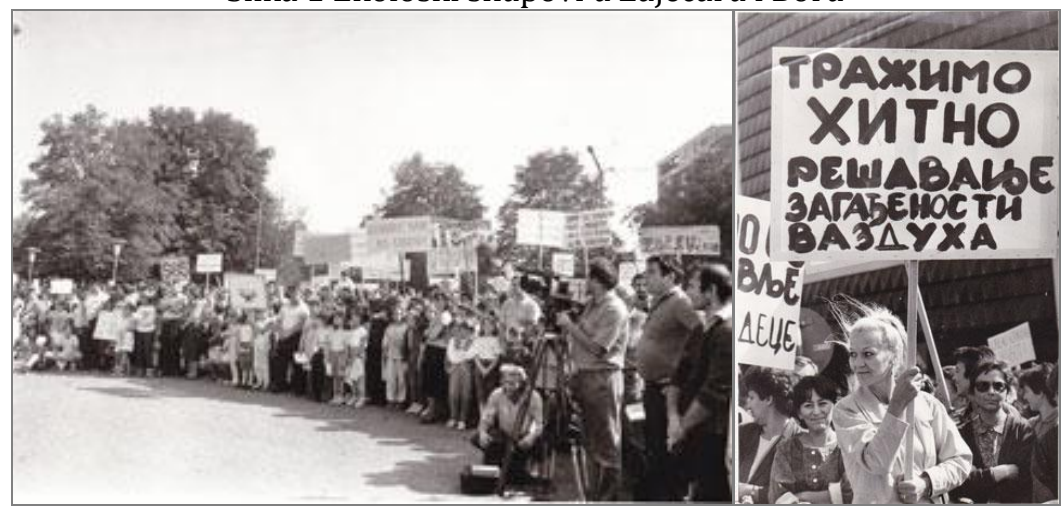

Such a public opinion process was inspired by the increased involvement of professional institutions from Zajecar and Bor, in solving the ecological crisis in the Timok Krajina region and establishing an environmental tribune "Ecological Truth".
The Stockholm Conference in 1972 and her echo in Timok Krajina

The first United Nations Conference on the Human Environment was held in Stockholm in 1972. This Stockholm Conference marked a 
milestone in the relationship between humanity and the environment. The first day of the Conference in Stockholm, June 5, was proclaimed World Environment Day (WED). From this Conference, a malicious, apocalyptic message spreads, that if the pollution and destruction of nature, continues at the same pace, life on earth will disappear in the next 50 years! Warning alarm was on as a reminder that natural resources can not be exploited uncontrollably and excessively without consequences for the overall humanity. In the focus of interest, the "polluters", protected by politics, were found in the focus of interest in the whole of the Timok River basin, and over the hill, in Majdanpek. Cadastres of polluters were being made rapidly. At first, the state was satisfied that "polluters" were paying expensive ecological taxes, because of the damage they inflict on nature. Problems to be solved are very complex and expensive for interventions to be taken on obsolete technologies and to make their harmful effect to nature more tolerable. The problems caused by the development of all cities and the urbanization of the Timok Krajina region should be also added to all this. There was a need to deal with the problems created by intensive industrialization of the Timok region by developing institutions and strategies based on science in the field of nature protection from industry and obsolete technologies.

Echo of the Conference in Rio in 1992 new approaches to ecology

The Rio de Janeiro Conference, twenty years after the Stockholm conference, focused on preserving natural values, especially on biodiversity. While the first was concerned with environmental issues, the second tackled environmental and developmental issues and was known as the World Earth Summit. The global concept of sustainable development was officially accepted and adopted at this conference [8].

The Institute for Health Protection "Timok" in Zajecar has introduced a new philosophy in the ecology of the Timok Krajina region, which also reflects on the contents of the work of "Ecological Truth". At the time when this was not taken into account in Serbia, and when many did not know what biodiversity is, the Institute initiated and organized the scientific conference "Our Ecological Truth", thus drawing attention to new approaches to ecology.

The following attitude is taken into account: it is better to protect natural biodiversity more effectively than to wage war with "polluters". So the issue of ecological education came to the agenda. The results of the research unambiguously indicated low ecological awareness among the population and insufficiently developed health culture.

The Institute offered a school system the Ecological education program, which began to be applied in some secondary schools in Bor and Zajecar. Elementary school in the village of Krivelj had organized for several years "School of ecology" in the village of Gornjane, to which came elementary school pupils from several cities from Serbia and Vojvodina. The papers about ecological education referenced in a series of scientific conferences of "Ecological Truth" is a proof of the echo the Conference in Rio had in our area.

Truth"

Community for Science and "Ecological

Nikola Sainovic started the founding of the Society for Science in Bor in 1986. The first scientific project for the protection of the human environment was related to the so-called. «Floodplain», created after the construction of the hydroelectric power plant " Djerdap I".
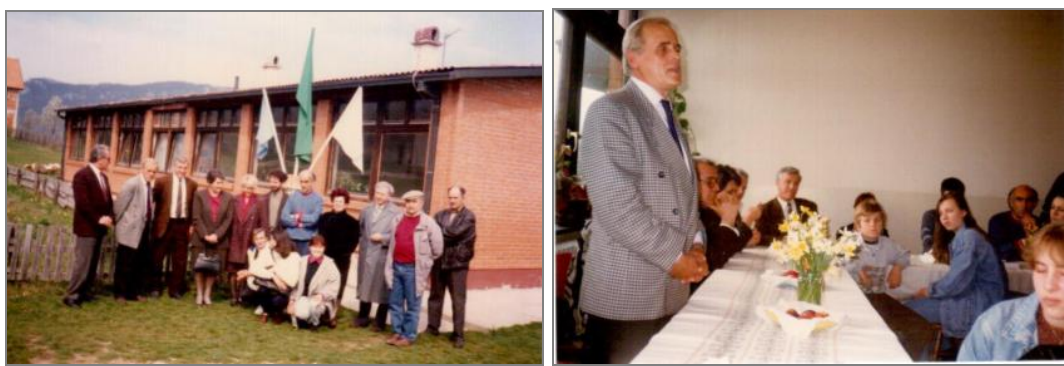
It was hosted by several institutions and researchers, led by Academician Vojislav Petrovic, professor of biology, born in Krajina, a former professor of Negotin Gymnasium. Several doctors from the area of the Timok region, who wanted a taste of the eternal grail of science, were also included in a large team of experts of the project. A microbiologist, a toxicologist and a doctor of preventive medicine were engaged in the Institute for Health Protection "Timok" Zajecar, together with the Institute for Copper in Bor and the Technical Faculty in Bor and the Institute seriously began to deal with ecology. We had laws, a scientific community, institutions, but there was something else missing: an environmental forum where research results, environmental ideas, research approaches, discussions, research and interventions in a damaged nature could be presented. And most importantly, to offer efficient expert solutions to factories and the state and to facilitate the implementation of environmental laws.

What was at first interesting was the fact that researchers began to pay attention to the risks and health-related hazards caused by industry and technology. And not only that.The presence and engagement of the Institute in Zajecar has contributed to the protection of nature with special values: moral, institutional and scientific.

During participation in the work of the Community of Science, Rade Kojdic - Cica, Director of the Institute of Copper Bor, Director of the Zavod for Health Protection "Timok" Zajecar, Dr Petar Paunovic, and Toplica Marjanovic from Bor, launched an initiative for holding an annual professional and scientific conference "Our Ecological Truth", later "Ecological Truth", today "Ecological Truth and Environmental Research".

The first Conference entitled "Our Ecological Truth", was held on June 5, 1993 in Zajecar. The representatives of the Ministry of Environmental Protection, local governments, businesses, NGOs, the media and doctors of medical centers of the cities in the region of Timok Krajina took part in the conference. The papers from this scientific conference were published in the Journal "Razvitak" in Zajecar.

Figure 3 Journal "Razvitak" from 1993

Slika 3 Časopis "Razvitak" iz 1993. godine

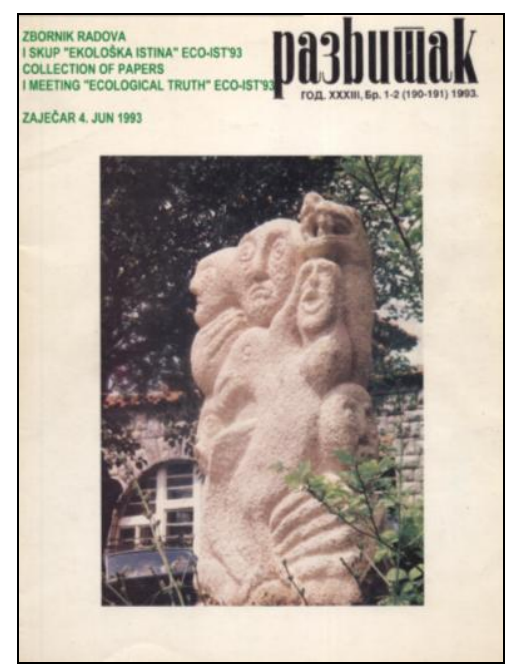

\section{Our Ecological Truth and Radioactive Waste from Vinca}

Soon after its establishment "Our Ecological Truth", slowly began to transform itself into ecological movement of Timok Krajina region. It has become a serious institution of ecological activities on political, professional and social plan. In the middle of the 90s, during a scientific and expert meeting held on Borsko Lake, Dr Jordan Aleksic, minister of Ecology and Environmental Protection of the Republic of Serbia, raised a question regarding the radioactive waste from Vinca, having a doubt that the waste had been deposited in the abandoned uranium mine in Kalna [9]. 
Kladovo Community has raised the issue of pollution of the Danube by radionuclides from the waste waters coming from those European countries through which this big river flows. The community was also looking for a solution on how to protect vegetable fields from the destruction caused by acid rains formed due to air polluted by industrial emissions from the factories in Turn Severin, in neighboring Romania. This opened up a space for researchers and topics that found their place in the programmes of scientific - expert meetings of Ecological Truth.

\section{LEAP - Local Environmental Action Plan}

Numerous and varied activities in the field of environmental protection enabled the LEAP - local environmental action plan to be created at the beginning of a new period in 2000 , in order to ensure the continuity of human environment protection. The largest number of municipalities in the Timok Krajina region have developed ecological plans upon state's directives, but these have not been revised, due to political and economic crisis. "Ecological truth" continued to live in spite of the war and the mentioned crisis.

TWENTY-FIVE YEARS OF ECOLOGICAL TRUTH

"Ecological Truth" is a traditional scientific and professional conference, today a conference devoted to environment, ecology, public health, sustainable development, and its primary goal is to raise ecological awareness. It has been held for 25 years and, most importantly, it fulfills this mission.

"Ecological Truth" began in 1993 as a national conference, later a national scientific with international participation, and today it is an international conference. In the past two decades, "Ecological Truth" has developed and gone through certain phases of its development. However, the years 1994, 1996, 1998, 1999, 2003 and 2010 represent the milestones in the development of the "Ecological Truth".

In the spring of 1994, the Institute offered cooperation to the Society of Young Researchers and to the Mining and Smelting Combine Bor to jointly continue with the organization of this event. This was one of the crucial moments when the foundations of future organization and cooperation were laid. On this occasion, some strategic decisions were made:

1. "Our Ecological Truth" was to become a multidisciplinary scientific-expert conference on natural values and environmental protection, where the latest scientific, theoretical, expert knowledge and practical experience of experts of different profiles (engineers, doctors, biologists, geographers, free planners, economists, lawyers, pedagogues) would be heard.

2. At the same time, the "Days of Preventive Medicine of Timok Krajina", which, by then, had already been organized for five years, was to be organized together with the "Ecological Truth".

3. Apart from the Institute, some other professional and scientific, health and economic organizations as well as non-governmental organizations from Bor and Zajecar would be included in the organization of the Conference.

4. The Conference should become traditional and be organized in all the cities of Timok Krajina.

According to the number of papers, authors and co-authors, as well as the participants, the second "(Our) Ecological Truth" was the most massive event to date. A Proceeding of abstract papers was prepared for the Conference (up to 2 pages per work).

Each new conference brought up some new dilemmas and sought answers to new questions. Preparations for the third conference began with the question: Should such a Conference be organized each year? Do we have enough knowledge, readiness, organizational and financial capabilities? The solution was found in the establishment of cooperation between professional and scientific institutions, economy, local self-government and nongovernmental sector, which ensured successful organization.

The following co-organization of the conference in 1995, included the only state higher education institution in the Timok Krajina region, the Technical faculty in Bor. The Technical faculty in Bor had actively participated in co-organizing of the event until 2002, and since 2003, until today, it has been the main organizer of the "Ecological Truth". During this period, the Technical faculty in Bor has made a considerable contribution to the realization of the idea begun in 1993 .

In 1996, this scientific conference was named "Ecological Truth" at the proposal of Assist. Prof. Dr. Goran Belojevic from the Institute of Hygiene and Medical Ecology at University of Belgrade, who was one of his regular participants. 
In 1998, it brought in some new things, which enriched the content and program of this event and brought it closer to the wider public. From the beginning, one of the basic goals of the Conference was the affirmation of the research work of young people. At the sixth meeting, in 1998, for the first time they had the opportunity to present their papers to pupils and students within the special section " Scientific youth", and this idea was also accepted at other scientific meetings in Serbia.

The "Ecological Truth" was the only traditional scientific conference organized in wartime in 1999. It was held in Zajecar on the last day of the NATO bombing and on the first day of peace.

Due to a large interest shown by many experts from the country and abroad, this conference further developed and on its 18th birthday in 2010, for the first time it was held as international conference and out of eastern Serbia. The venue was in Banja Junakovic near Apatin, in Vojvodina. Accepted papers are printed in English in Proceedings. The title of the conference was the International Conference "Ecological Truth", officially used by 2017. The late Prof. Dr. Zoran S. Markovic then stated: „This is one of the multidisciplinary, international conferences in Serbia that has the official approval of the Ministry of Education, Science and Technological Development."

In 2010, of the previous co-organizers, there only remained the Society of Young Researchers from Bor; new co-organizers were: Zapadno Васка Administrative District Sombor, Public Health Institute of Sombor, Vojvodina Forest of Sombor, Chamber of Commerce Novi Sad, DP „Agroinstitut“ Sombor, Municipality of Apatin and Sombor City.

Figure 4 Participants of the "Ecological Truth" in Zajecar, 1999.

Slika 4 Učesnici "Ekološke istine" u Zaječaru, 1999. godina

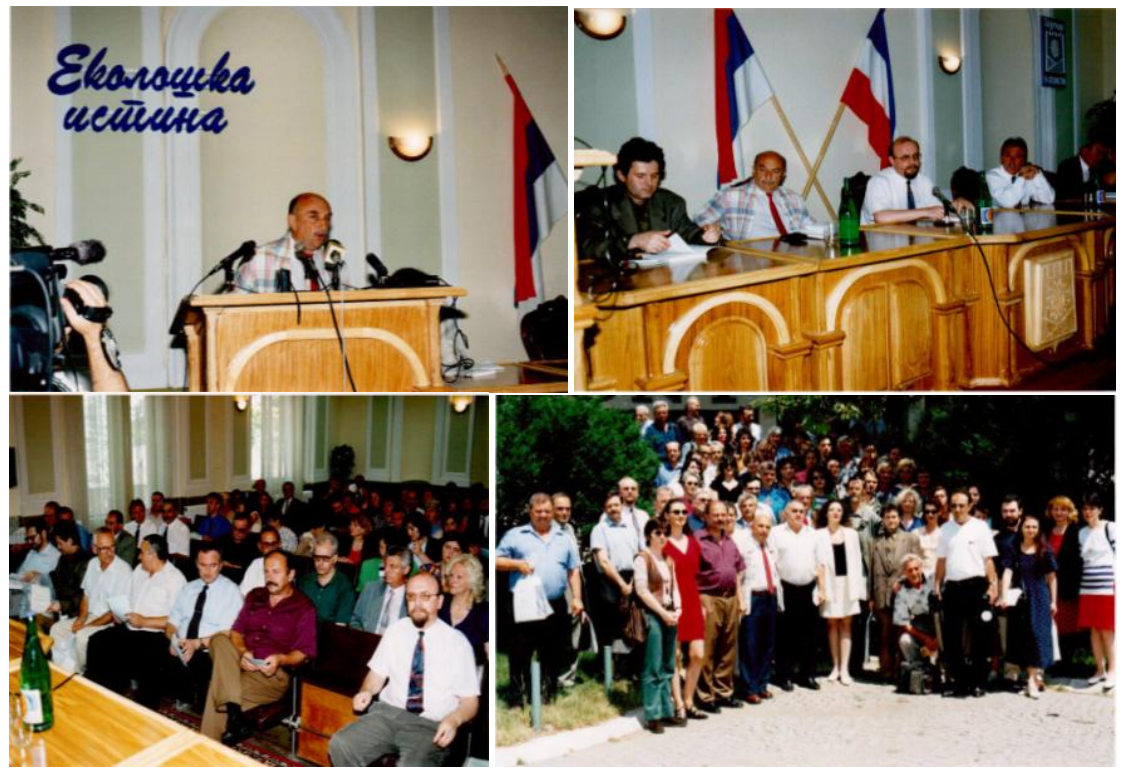

Bearing in mind that in the realization and affirmation of "Ecological Truth", various government, professional and scientific and numerous non-governmental organizations have participated from the very beginning, it is necessary to get to know the nature and basic characteristics of "Ecological Truth".

The basic characteristics of the Conference "Ecological Truth" are:

- Science and expertise: the main goal is the presentation of scientific and professional papers reviewed by the Scientific Committee. All papers were published in special Proceedings, which affirmed the participants and their ecological activities.

Multidisciplinarity

and interdisciplinarity: the organizer's desire was to gather experts from different profiles at the same place and to share knowledge about the environment and people's health from 
the aspect of different sciences, and also to point out possible solutions to the same topic.

- Relevancy and adaptability to the needs of the time: the number of different topics and sections in which they are dealt with can always be searched for current scientific developments and practical needs of the society. Some sections expanded their scope of work and introduced new sections with contemporary content, for example, since 2001, there has been a session on the Local Environmental Action Plans (LEAP), which became a special topic at the moment when we began to talk about these plans.

- Affirmation of research work of young people: since the first scientific conference special attention has been paid to the affirmation of the research work of young people.

- Co-operation and capacity building of the local community: the organization of such an event required the establishment of cooperation of the entire community. One of the goals was to achieve cooperation and strengthen the capacities of all sectors: government (local self-government), business sector, professional and scientific institutions and non-governmental organizations.

- Publicity: the conference is seen as an opportunity to inform the public about new scientific knowledge about the environment. Therefore, from the beginning, all the information has been available to the media and every opportunity was used to talk and write about it.

An analysis of the results achieved at the professional and scientific conference "Ecological truth" is one of the basic tasks of the author of this lecture. Tables 1 to 8 provide statistical analysis of results and events in the period from 1993 to 2017.

The number of published papers at the conference "Ecological Truth" from 1993 to 2017 is presented in tables $1-3$.

Table 1 Number of published papers on the national scientific and professional conference "Our Ecological Truth" (1993-2002)

Tabela 1 Broj objavljenih radova nacionalne naučno-stručne konferencije "Naša Ekološka istina" (1993-2002)

\begin{tabular}{|c|c|c|c|c|c|c|c|c|c|c|c|}
\hline \multirow{3}{*}{ SEKCIJA } & \multicolumn{11}{|c|}{ OUR ECOLOGICAL TRUTH } \\
\hline & \multicolumn{11}{|c|}{ Ordinal numbers of Conferences } \\
\hline & $\mathrm{I}$ & II & III & IV & $\mathrm{V}$ & VI & VII & VIII & IX & $\mathrm{X}$ & $\sum$ \\
\hline EI1. Plenary lectures & 10 & - & - & - & - & - & - & - & - & - & 10 \\
\hline $\begin{array}{l}\text { EI2. Technology and the state of } \\
\text { environment }\end{array}$ & - & 61 & 55 & 45 & 44 & 26 & 5 & 20 & 22 & 20 & 298 \\
\hline $\begin{array}{l}\text { EI3. Protection and preservation of natural } \\
\text { resources }\end{array}$ & - & 33 & 18 & 12 & 20 & 18 & 13 & 21 & 18 & 13 & 165 \\
\hline EI4. Ecological education & - & 11 & 11 & 8 & 21 & 6 & 11 & 20 & 10 & 13 & 111 \\
\hline $\begin{array}{l}\text { EI5. Water accumulation - state, problems } \\
\text { and perspectives }\end{array}$ & - & 5 & 7 & - & - & - & - & - & - & - & 12 \\
\hline EI6. Use and water protection & - & - & - & - & - & 9 & 8 & 8 & 11 & 12 & 48 \\
\hline EI7. Food and nutrition of the people & - & 13 & 13 & - & - & - & - & - & - & - & 26 \\
\hline EI8. Nutrition and health & & & & & & & & 12 & 10 & 10 & 32 \\
\hline EI9. Agriculture & - & - & - & - & - & - & 10 & 10 & 10 & 8 & 38 \\
\hline $\begin{array}{l}\text { EI10. Economy and environmental } \\
\text { protection, standardization and } \\
\text { homologization of standards }\end{array}$ & - & & 6 & 5 & - & - & - & - & - & - & 11 \\
\hline EI11. Ecological management & - & - & - & - & - & 7 & 2 & 14 & 13 & & 36 \\
\hline EI12. Urban ecology & - & - & - & - & - & - & 5 & 11 & 9 & 20 & 45 \\
\hline EI13. Sustainable tourism & - & - & - & - & - & - & - & - & - & 5 & 5 \\
\hline TOTAL EI & 10 & 123 & 110 & 70 & 85 & 66 & 54 & 116 & 103 & 101 & 838 \\
\hline \multirow{3}{*}{ SESSION } & & & DAY & $\mathrm{FPR}$ & NTII & MEDI & $\mathrm{JE} \mathrm{OH}$ & $\mathrm{MOK}$ & $\mathrm{AJIN}$ & & \\
\hline & \multicolumn{11}{|c|}{ Ordinal numbers of Conferences } \\
\hline & 6. & 7. & 8. & 9. & 10. & 11. & 12. & 13. & 14. & 15. & $\sum$ \\
\hline PM1. Environment and heath & - & 12 & 18 & - & - & 4 & - & - & - & - & 34 \\
\hline
\end{tabular}




\begin{tabular}{|c|c|c|c|c|c|c|c|c|c|c|c|}
\hline PM2. Energy and health & - & - & - & - & - & - & - & - & 4 & - & 4 \\
\hline PM3. Migration and health & - & - & - & 2 & 1 & - & - & - & - & - & 3 \\
\hline PM4. Demographic processes in SRJ & - & - & - & - & - & 4 & 1 & 6 & 9 & 18 & 38 \\
\hline PM5. Preventive medicine & - & - & 8 & - & - & - & - & - & - & - & 8 \\
\hline $\begin{array}{l}\text { PM6. Preventive medicine in health } \\
\text { protection today }\end{array}$ & - & - & 6 & - & - & - & - & - & - & - & 6 \\
\hline $\begin{array}{l}\text { PM7. Health of people during the last } \\
\text { decade of the XX century }\end{array}$ & - & - & - & 19 & - & - & - & - & - & - & 19 \\
\hline $\begin{array}{l}\text { PM8. Prevention and suppression of } \\
\text { chronic mass disorders of health - modern } \\
\text { achievements }\end{array}$ & - & - & - & - & - & - & 7 & 11 & 8 & 3 & 29 \\
\hline $\begin{array}{l}\text { PM9. Social- ecological health model in } \\
\text { theory and practice }\end{array}$ & - & - & - & - & 12 & 7 & - & - & - & 16 & 35 \\
\hline $\begin{array}{l}\text { PM10. Health education and social } \\
\text { medicine }\end{array}$ & - & 15 & - & - & - & - & - & - & - & - & 15 \\
\hline PM11. Hygiene & - & 30 & - & - & - & - & - & - & - & - & 30 \\
\hline PM12. Epidemiology and microbiology & - & 28 & - & - & - & - & - & - & - & - & 28 \\
\hline $\begin{array}{l}\text { PM13. Modern ecological-epidemiological } \\
\text { approachin solving natural focal infections }\end{array}$ & - & - & - & 3 & 2 & - & - & - & - & - & 5 \\
\hline PM14. Quality control of immunization & - & - & 4 & 1 & - & - & - & - & - & - & 5 \\
\hline PM15. Lyme, 20 years later & - & 11 & - & - & - & - & - & - & - & - & 11 \\
\hline PM16. Microbes and people & - & - & - & 9 & 7 & 11 & 6 & 15 & 14 & 7 & 69 \\
\hline TOTAL PM & 0 & 96 & 36 & 34 & 22 & 26 & 14 & 32 & 35 & 44 & 339 \\
\hline & \multicolumn{11}{|c|}{ SPECIAL SESSIONS } \\
\hline PS1. Scientific and research projects & - & - & - & - & - & 4 & - & 1 & 1 & 2 & 8 \\
\hline $\begin{array}{l}\text { PS2. National and local ecological action } \\
\text { plans }\end{array}$ & - & - & - & - & - & - & - & - & 2 & 6 & 8 \\
\hline PS3. Scientific youth & - & - & - & - & - & 12 & - & 19 & 26 & 31 & 88 \\
\hline TOTAL PS & 0 & 0 & 0 & 0 & 0 & 16 & 0 & 20 & 29 & 39 & 104 \\
\hline TOTAL PAPERS (EI+PM+PS) & 10 & 219 & 146 & 104 & 107 & 108 & 68 & 168 & 167 & 184 & 1281 \\
\hline
\end{tabular}

Table 2 Number of published papers on the scientific and professional conference on natural resources and environmental protection "Ecological Truth" (2003-2009)

Tabela 2 Broj objavljenih radova nacionalne naučno-stručne konferencije na temu prirodnih resursa i zaštite životne sredine "Ekološka istina" (2003-2009)

\begin{tabular}{|c|c|c|c|c|c|c|c|c|}
\hline \multirow{3}{*}{ SESSION } & \multicolumn{8}{|c|}{$\begin{array}{c}\text { SCIENTIFIC AND PROFESSIONAL CONFERENCE } \\
\text { ON NATURAL RESOURCES AND ENVIRONMENTAL PROTECTION } \\
\text { "ECOLOGICAL TRUTH" }\end{array}$} \\
\hline & \multicolumn{8}{|c|}{ Ordinal numbers of Conferences } \\
\hline & $\mathrm{XI}$ & XII & XIII & XIV & $\mathrm{XV}$ & XVI & XVII & $\sum$ \\
\hline EI1. Plenary lectures & 4 & 2 & 1 & 1 & 1 & 1 & 5 & 15 \\
\hline $\begin{array}{l}\text { EI2. Protection and preservation of natural } \\
\text { resources }\end{array}$ & 23 & 16 & 14 & 14 & 14 & 17 & 18 & 116 \\
\hline $\begin{array}{l}\text { EI3. Technologies, wastes recycling and the } \\
\text { environment }\end{array}$ & 22 & 22 & 31 & 28 & 18 & 31 & - & 152 \\
\hline $\begin{array}{l}\text { EI4. Technological aspects - natural values and } \\
\text { their protection }\end{array}$ & - & - & - & - & - & - & 20 & 20 \\
\hline EI5. Nutrition and health & 5 & 5 & 13 & 3 & 5 & 6 & 10 & 47 \\
\hline EI6. Agriculture & 3 & 14 & 11 & 13 & 14 & 12 & - & 67 \\
\hline EI7. Urban ecology & 20 & 15 & 13 & 11 & 14 & 8 & - & 81 \\
\hline EI8. Air protection & - & - & - & - & - & - & 13 & 13 \\
\hline EI9. Water supply and protection & 10 & 10 & 19 & 9 & 7 & 7 & 7 & 69 \\
\hline EI10. Land protection & - & - & - & - & - & - & 6 & 6 \\
\hline EI11. Energy efficiency & - & - & - & - & - & 3 & - & 3 \\
\hline $\begin{array}{l}\text { EI12. Waste management and secundary } \\
\text { materials recycling }\end{array}$ & - & - & - & - & 12 & 12 & - & 24 \\
\hline EI13. Ecological management & 5 & 7 & 8 & 9 & 9 & 5 & - & 43 \\
\hline $\begin{array}{l}\text { EI14. Ecological ethics, ecological education, NGO } \\
\text { and the environment }\end{array}$ & 8 & 9 & 10 & 6 & 13 & 5 & - & 51 \\
\hline
\end{tabular}




\begin{tabular}{|c|c|c|c|c|c|c|c|c|}
\hline EI15. Municipality and environmental protection & - & - & - & - & - & 2 & 26 & 28 \\
\hline EI16. Sustainable development & - & - & - & - & 12 & 7 & - & 19 \\
\hline EI17. Sustainable tourism & 5 & 4 & 6 & 16 & - & - & - & 31 \\
\hline EI18. Round table & - & - & - & 3 & 3 & 3 & - & 9 \\
\hline TOTAL EI & 105 & 104 & 126 & 113 & 122 & 119 & 105 & 794 \\
\hline \multicolumn{9}{|c|}{ DAYS OF PREVENTIVE MEDICINE OF TIMOK KRAJINA } \\
\hline \multirow[t]{2}{*}{ SESSION } & \multicolumn{8}{|c|}{ Ordinal numbers of Conferences } \\
\hline & 16. & 17. & 18. & 19. & 20. & 21. & 22. & $\sum$ \\
\hline $\begin{array}{l}\text { PM1. Socio-ecological health model in theory and } \\
\text { practice }\end{array}$ & 6 & 2 & \multirow{2}{*}{12} & - & 6 & \multirow{4}{*}{12} & - & \multirow{4}{*}{93} \\
\hline $\begin{array}{l}\text { PM2. Prevention and eradication of massive } \\
\text { health disorders - the latest developments }\end{array}$ & 3 & 15 & & - & 5 & & - & \\
\hline $\begin{array}{l}\text { PM3. Microbes and people (interweaving of } \\
\text { macro and micro environment in all spheres of } \\
\text { life }\end{array}$ & 5 & - & - & - & - & & - & \\
\hline PM4. Demographic processes & 14 & 4 & 9 & - & - & & - & \\
\hline \multirow[t]{2}{*}{ TOTAL PM } & 28 & 21 & 21 & 0 & 11 & 12 & 0 & 93 \\
\hline & \multicolumn{8}{|c|}{ SPECIAL SESSIONS } \\
\hline PS1. Scientific and research projects & - & 3 & \multirow{2}{*}{3} & \multirow{3}{*}{2} & - & - & - & \multirow{2}{*}{16} \\
\hline PS2. National and local ecological action plans & 6 & 2 & & & - & - & - & \\
\hline PS3. Scientific youth & 16 & 23 & - & & 4 & 5 & 12 & 60 \\
\hline TOTAL PS & 22 & 28 & 3 & 2 & 4 & 5 & 12 & 76 \\
\hline TOTAL PAPERS (EI+PM+PS) & 155 & 153 & 150 & 115 & 137 & 136 & 117 & 963 \\
\hline
\end{tabular}

Tabela 3 Number of published papers on the International scientific - professional conference "Ecological Truth"(2010-2017)

Tabela 3 Broj objavljenih radova o međunarodnoj naučno-stručnoj konferenciji “Ekološka istina”(20102017)

\begin{tabular}{|c|c|c|c|c|c|c|c|c|c|}
\hline \multirow{3}{*}{ SESSION } & \multicolumn{9}{|c|}{$\begin{array}{l}\text { INTERNATIONAL SCIENTIFIC AND PROFESSIONAL CONFERENCE } \\
\text { "ECOLOGICAL TRUTH" }\end{array}$} \\
\hline & \multicolumn{9}{|c|}{ Ordinal numbers of Conferences } \\
\hline & XVIII & XIX & $\mathrm{XX}$ & XXI & XXII & XXIII & XXIV & $\mathrm{XXV}$ & $\sum$ \\
\hline EI1. Plenary lectures & - & 2 & 2 & 1 & 1 & 4 & 4 & 5 & 19 \\
\hline $\begin{array}{l}\text { EI2. Protection and preservation of natural } \\
\text { resources }\end{array}$ & 10 & 10 & 18 & 10 & 7 & 8 & 7 & 5 & 75 \\
\hline $\begin{array}{l}\text { EI3. Technologies, wastes recycling and the } \\
\text { environment }\end{array}$ & 26 & 26 & 24 & 29 & 30 & 47 & 40 & 31 & 253 \\
\hline $\begin{array}{l}\text { EI4. Energy efficiency, environment and } \\
\text { climate }\end{array}$ & 6 & 6 & 1 & 5 & 7 & 7 & 8 & - & 40 \\
\hline EI5. Soil and water conservation engineering & 10 & - & 10 & 13 & 4 & - & 19 & 8 & 64 \\
\hline $\begin{array}{l}\text { EI6. Agriculture: agribusiness, agro- } \\
\text { engineering and organic food production }\end{array}$ & 5 & 5 & 2 & - & 5 & 7 & 8 & - & 32 \\
\hline EI7. Nutrition and health & 4 & - & 1 & 4 & - & - & 5 & 8 & 22 \\
\hline EI8. Urban ecology & 5 & 12 & 15 & 6 & 5 & 13 & - & - & 56 \\
\hline EI9. Water supply and protection & 3 & 9 & - & - & 6 & 4 & - & 6 & 28 \\
\hline $\begin{array}{l}\text { EI10. Ecological management (Law, economy, } \\
\text { standardization) }\end{array}$ & 3 & 6 & 5 & 13 & 13 & 6 & 17 & 7 & 70 \\
\hline $\begin{array}{l}\text { EI11. Ecological ethics and ecological } \\
\text { education }\end{array}$ & 3 & 7 & 3 & 4 & 4 & 6 & 14 & - & 41 \\
\hline EI12. Environmental ampact assessment & 4 & 1 & 1 & 9 & 5 & - & - & 19 & 39 \\
\hline $\begin{array}{l}\text { EI13. Eco tourism and sustainable } \\
\text { development }\end{array}$ & 3 & 4 & 4 & 3 & 3 & 7 & - & 7 & 31 \\
\hline EI14. Preventive medicine and ecology & 5 & 14 & 4 & 7 & 6 & 7 & 6 & - & 49 \\
\hline TOTAL EI & 87 & 102 & 90 & 104 & 96 & 116 & 128 & 96 & 819 \\
\hline
\end{tabular}




\begin{tabular}{|l|c|c|c|c|c|c|c|c|c|}
\hline PS1. Students' papers & 1 & 6 & 9 & 4 & - & - & - & - & 20 \\
\hline TOTAL PS & 1 & 6 & 9 & 4 & 0 & 0 & 0 & 0 & 20 \\
\hline TOTAL PAPERS (EI+PS) & 88 & 108 & 99 & 108 & 96 & 116 & 128 & 96 & 839 \\
\hline
\end{tabular}

The organizers and co-organizers of the conference "Ecological Truth" from 1993 to 2017 are presented in tables $4-6$. The venue and the Presidents of the Scientific and Organizing committee of the conference
"Ecological Truth" from 1993 to 2017 are presented in table 7 . The number of authors and publications of papers at the conference "Ecological Truth" from 1993 to 2017 are presented in table 8 , too.

Table 4 Organizers and co-organizers of the national scientific and professional meetings

"Our Ecological Truth" (1993-2002)

Tabela 4 Organizatori i suorganizatori nacionalnih naučno-stručnih skupova

"Naša Ekološka istina" (1993-2002)

\begin{tabular}{|l|c|c|c|c|c|c|c|c|c|c|}
\hline \multicolumn{1}{|c}{ ORGANIZER } & \multicolumn{7}{c|}{ OUR ECOLOGICAL TRUTH } \\
\hline & I & II & III & IV & V & VI & VII & VIII & IX & X \\
\hline University of Belgrade, Technical Faculty in Bor & & & X & X & X & X & X & X & X & X \\
\hline Institute for Public Health "Timok" Zajecar & $\mathrm{X}$ & $\mathrm{X}$ & $\mathrm{X}$ & $\mathrm{X}$ & $\mathrm{X}$ & $\mathrm{X}$ & $\mathrm{X}$ & $\mathrm{X}$ & $\mathrm{X}$ & $\mathrm{X}$ \\
\hline Society of Young Researchers Bor & & $\mathrm{X}$ & $\mathrm{X}$ & $\mathrm{X}$ & $\mathrm{X}$ & $\mathrm{X}$ & $\mathrm{X}$ & $\mathrm{X}$ & $\mathrm{X}$ & $\mathrm{X}$ \\
\hline Institute for copper Bor & & $\mathrm{X}$ & & & & & & $\mathrm{X}$ & & \\
\hline RTB BOR Group & & $\mathrm{X}$ & $\mathrm{X}$ & & & & & & & \\
\hline Health Center Bor & & $\mathrm{X}$ & $\mathrm{X}$ & & & & & & & \\
\hline Ministry of Environment and Development SRJ & & $\mathrm{X}$ & & & & & & & & \\
\hline Ministry of Environmental Protection RS & & $\mathrm{X}$ & & & & & & & & \\
\hline Community of Negotin & & & & & & $\mathrm{X}$ & & & & \\
\hline Center for Agricultural Research Zajecar & & & & & & $\mathrm{X}$ & $\mathrm{X}$ & $\mathrm{X}$ & $\mathrm{X}$ & $\mathrm{X}$ \\
\hline Ecological movement "Dubasnica" & & & & & & $\mathrm{X}$ & & & & \\
\hline
\end{tabular}

Table 5 Organizers and co-organizers of the scientific and professional conference on natural resources and environmental protection "Ecological Truth" (2003-2009)

Tabela 5 Organizatori i suorganizatori naučno-stručne konferencije na temu prirodnih resursa i zaštite životne sredine "Ekološka istina" (2003-2009)

\begin{tabular}{|c|c|c|c|c|c|c|c|}
\hline \multirow[t]{3}{*}{ ORGANIZER } & \multicolumn{7}{|c|}{$\begin{array}{c}\text { SCIENTIFIC AND PROFESSIONAL CONFERENCE ON NATURAL RESOURCES AND } \\
\text { ENVIRONMENTAL PROTECTION } \\
\text { "ECOLOGICAL TRUTH" }\end{array}$} \\
\hline & $\mathrm{XI}$ & XII & XIII & XIV & $\mathrm{XV}$ & XVI & XVII \\
\hline & EkoIst'03 & EkoIst'04 & EkoIst'05 & EkoIst'06 & \begin{tabular}{|l|} 
EkoIst'07 \\
\end{tabular} & \begin{tabular}{|l|} 
EkoIst'08 \\
\end{tabular} & EkoIst'09 \\
\hline University of Belgrade, Technical Faculty in Bor & $\mathrm{X}$ & $\mathrm{X}$ & $\mathrm{X}$ & $\mathrm{X}$ & $\mathrm{X}$ & $\mathrm{X}$ & $\mathrm{X}$ \\
\hline Institute for Public Health - Zajecar & $\mathrm{X}$ & $\mathrm{X}$ & $\mathrm{X}$ & $\mathrm{X}$ & $\mathrm{X}$ & $\mathrm{X}$ & $\mathrm{X}$ \\
\hline Society of Young Researchers Bor & $\mathrm{X}$ & $\mathrm{X}$ & $\mathrm{X}$ & $\mathrm{X}$ & $\mathrm{X}$ & $\mathrm{X}$ & $\mathrm{X}$ \\
\hline \multicolumn{8}{|l|}{ Institute of Mining and Metallurgy - Bor } \\
\hline Center for Agricultural Research Zajecar & $\mathrm{X}$ & $\mathrm{X}$ & $\mathrm{X}$ & $\mathrm{X}$ & $\mathrm{X}$ & $\mathrm{X}$ & \\
\hline \multicolumn{8}{|l|}{ RTB BOR Group } \\
\hline \multicolumn{8}{|l|}{ Health Center Bor } \\
\hline \multicolumn{8}{|l|}{ Ministry of Environment and Development SRJ } \\
\hline \multicolumn{8}{|l|}{ Ministry of Environmental Protection RS } \\
\hline \multicolumn{8}{|l|}{ Community of Negotin } \\
\hline \multicolumn{8}{|l|}{ Ecological movement "Dubasnica" } \\
\hline University of Nis, Faculty of Occupational Safety Nis & & & & & $\mathrm{X}$ & $\mathrm{X}$ & \\
\hline
\end{tabular}


Table 6 Organizers and co-organizers of the International scientific - professional conference

"Ecological Truth" (2010-2017)

Tabela 6 Organizatori i suorganizatori međunarodne naučno-stručne konferencije

" Ekološka istina " (2010-2017)

\begin{tabular}{|c|c|c|c|c|c|c|c|c|}
\hline \multirow{3}{*}{ ORGANIZER } & \multicolumn{8}{|c|}{$\begin{array}{c}\text { INTERNATIONAL SCIENTIFIC } \\
\text { AND PROFESSIONAL CONFERENCE "ECOLOGICAL TRUTH" }\end{array}$} \\
\hline & XVIII & XIX & $\mathrm{XX}$ & XXI & XXII & XXIII & XXIV & XXV \\
\hline & $\begin{array}{l}\text { Eco- } \\
\text { Ist'10 }\end{array}$ & $\begin{array}{l}\text { Eco- } \\
\text { Ist'11 }\end{array}$ & Eco-Ist'12 & Eco-Ist'13 & |Eco-Ist'14 & Eco-Ist'15 & Eco-Ist'16 & $\begin{array}{l}\text { Eco- } \\
\text { Ist'17 }\end{array}$ \\
\hline University of Belgrade, Technical Faculty in Bor & $\mathrm{X}$ & $\mathrm{X}$ & $\mathrm{X}$ & $\mathrm{X}$ & $\mathrm{X}$ & $\mathrm{X}$ & $\mathrm{X}$ & $\mathrm{X}$ \\
\hline Institute for Public Health - Zajecar & & $\mathrm{X}$ & $\mathrm{X}$ & & & & & \\
\hline Society of Young Researchers Bor & $\mathrm{X}$ & $\mathrm{X}$ & $\mathrm{X}$ & $\mathrm{X}$ & $\mathrm{X}$ & $\mathrm{X}$ & $\mathrm{X}$ & $\mathrm{X}$ \\
\hline Institute of Mining and Metallurgy - Bor & & $\mathrm{X}$ & $\mathrm{X}$ & $\mathrm{X}$ & $\mathrm{X}$ & & & $\mathrm{X}$ \\
\hline Institute for Nature Conservation of Serbia -Belgrade & & $\mathrm{X}$ & $\mathrm{X}$ & & $\mathrm{X}$ & $\mathrm{X}$ & $\mathrm{X}$ & $\mathrm{X}$ \\
\hline Bor Administrative District - Bor & & $\mathrm{X}$ & & & & & & \\
\hline Community of Bor & & $\mathrm{X}$ & & & & & & \\
\hline Touristic Organization "Bor" - Bor & & $\mathrm{X}$ & & & & & & \\
\hline Students Alliance Bor - Bor & & $\mathrm{X}$ & $\mathrm{X}$ & & $\mathrm{X}$ & & & \\
\hline West Backa Administrative District - Sombor & $\mathrm{X}$ & & & & & & & \\
\hline Institute for Public Health Sombor & $\mathrm{X}$ & & & & & & & \\
\hline "Vojvodina forests"Property of Sombor & $\mathrm{X}$ & & & & & & & \\
\hline Regional Chamber of Commerce - Novi Sad & $\mathrm{X}$ & & & & & & & \\
\hline Agriculture Professional Service - Sombor & $\mathrm{X}$ & & & & & & & \\
\hline Community of Apatin & $\mathrm{X}$ & & & & & & & \\
\hline Town Sombor & $\mathrm{X}$ & & & & & & & \\
\hline RTB BOR Group & & & & $\mathrm{X}$ & & & & \\
\hline Freeport-McMoRan Copper \& Gold Inc. & & & & $\mathrm{X}$ & & & & \\
\hline Rakita Exploration Bor & & & & $\mathrm{X}$ & & & & \\
\hline Geoing Group Beograd & & & & $\mathrm{X}$ & & & & \\
\hline British-Serbian Chamber of Commerce & & & & $\mathrm{X}$ & & & & \\
\hline $\begin{array}{l}\text { University of Montenegro, Faculty of Metallurgy and } \\
\text { Technology Podgorica, Montenegro }\end{array}$ & & & & & $\mathrm{X}$ & & & \\
\hline $\begin{array}{l}\text { University of Zagreb, Faculty of Metallurgy Sisak, } \\
\text { Croatia }\end{array}$ & & & & & $\mathrm{X}$ & $\mathrm{X}$ & $\mathrm{X}$ & $\mathrm{X}$ \\
\hline $\begin{array}{l}\text { University Christian "Dimitrie Cantemir", } \\
\text { Faculty of Management in Tourism and Commerce } \\
\text { Timisoara, Romania }\end{array}$ & & & & & $\mathrm{X}$ & $\mathrm{X}$ & $\mathrm{X}$ & $\mathrm{X}$ \\
\hline $\begin{array}{l}\text { University in Banja Luka, Faculty of Technology, } \\
\text { Banja Luka, RS, B\&H }\end{array}$ & & & & & & & $\mathrm{X}$ & \\
\hline $\begin{array}{l}\text { University of Pristina, Faculty of Technical Science, } \\
\text { Kosovska Mitrovica, Serbia }\end{array}$ & & & & & & $\mathrm{X}$ & $\mathrm{X}$ & $\mathrm{X}$ \\
\hline
\end{tabular}

Table 7 Venue and the Presidents of the Scientific and Organizing committees

Tabela 7 Mesto održavanja konferencije i Predsednici Naučnog i Organizacionog komiteta

\begin{tabular}{|l|l|l|l|}
\hline \multicolumn{1}{|c|}{ Conference } & \multicolumn{1}{|c|}{ Venue } & President of the Scientific Committee & President of the Organizing Committee \\
\hline I & Zajecar & & Petar Paunovic \\
\hline II & Borsko jezero & Dr Rade Kojdic & Toplica Marjanovic \\
\hline III & Borsko jezero & Dr Petar Paunovic & Zvonimir Milijic \\
\hline IV & Kladovo & Prof. dr Nedeljko Magdalinovic & Ljubiša Đorđevic \\
\hline V & Donji Milanovac & Prof. dr Berislav Ristic & Toplica Marjanovic \\
\hline VI & Negotin & Prof. dr Stevan Stankovic & Srđan Markovic \\
\hline VII & Zajecar & Prof. dr Stevan Stankovic & Dušan Pejcic \\
\hline VIII & Soko Banja & Prof. dr Stevan Stankovic & Nadežda Nikolic \\
\hline IX & Donji Milanovac & Prof. dr Zvonimir Stankovic & Predrag Marušic
\end{tabular}




\begin{tabular}{|l|l|l|l|}
\hline X & Donji Milanovac & Prof. dr Stevan Stankovic & Predrag Marušic \\
\hline XI & Donji Milanovac & Prof. dr Stevan Stankovic & Doc. dr Radoje Pantovic \\
\hline XII & Borsko jezero & Prof. dr Stevan Stankovic & Prof. dr Zoran Markovic \\
\hline XIII & Borsko jezero & Prof. dr Stevan Stankovic & Prof. dr Zoran Markovic \\
\hline XIV & Soko Banja & Prof. dr Stevan Stankovic & Prof. dr Milan Trumic \\
\hline XV & Soko Banja & Prof. dr Stevan Stankovic & Prof. dr Milan Trumic \\
\hline XVI & Soko Banja & Prof. dr Stevan Stankovic & Prof. dr Milan Trumic \\
\hline XVII & Kladovo & Prof. dr Stevan Stankovic & Prof. dr Zvonimir Stankovic \\
\hline XVIII & Banja Junakovic, Apatin & Prof. dr Zoran Markovic & Prof. dr Zoran Markovic \\
\hline XIX & Bor & Prof. dr Zoran Markovic & Prof. dr Zoran Markovic \\
\hline XX & Zajecar & Prof. dr Milan Antonijevic & Prof. dr Zoran Markovic \\
\hline XXI & Borsko jezero & Prof. dr Radoje Pantovic & Prof. dr Radoje Pantovic \\
\hline XXII & Borsko jezero & Prof. dr Milan Antonijevic & Prof. dr Radoje Pantovic \\
\hline XXIII & Kopaonik & Prof. dr Milan Antonijevic & Prof. dr Radoje Pantovic \\
\hline XXIV & Vrnjacka Banja & Prof. dr Dragana Zivkovic & Prof. dr Radoje Pantovic \\
\hline XXV & Vrnjacka Banja & Prof. dr Zoran Markovic & Prof. dr Radoje Pantovic \\
\hline
\end{tabular}

Table 8 Number of authors and publications of papers Tabela 8 Broj autora i objavljivanje radova

\begin{tabular}{|c|c|c|c|c|}
\hline \multirow{2}{*}{ Conference } & \multirow{2}{*}{ Number of authors and co-authors } & \multicolumn{3}{|l|}{ Publication of papers } \\
\hline & & \begin{tabular}{r|} 
Publication \\
\end{tabular} & Number of pages & Format \\
\hline$I$ & 20 & Journal "Razvitak" & 20 & \\
\hline II & 410 & Proceedings & 300 & $B 5$ \\
\hline III & 260 & Proceedings & 678 & $B 5$ \\
\hline$I V$ & 250 & Proceedings & 510 & B5 \\
\hline$V$ & 230 & Proceedings & 572 & $B 5$ \\
\hline$V I$ & 200 & Proceedings & 492 & $B 5$ \\
\hline VII & 100 & Proceedings & 346 & $B 5$ \\
\hline VIII & 260 & Proceedings & $728+216$ & $B 5$ \\
\hline$I X$ & 240 & Proceedings & 680 & $A 4$ \\
\hline$X$ & 300 & Proceedings & 662 & A4 \\
\hline$X I$ & 314 & Proceedings & 560 & A4 \\
\hline$X I I$ & 291 & Proceedings & 672 & $B 5$ \\
\hline$X I I I$ & 261 & Proceedings & 718 & $B 5$ \\
\hline$X I V$ & 210 & Proceedings & 619 & $B 5$ \\
\hline$X V$ & 267 & Proceedings & 746 & $B 5$ \\
\hline$X V I$ & 272 & Proceedings & 664 & $B 5$ \\
\hline$X V I I$ & 252 & Proceedings & 452 & $B 5$ \\
\hline XVIII & 213 & Proceedings & 539 & $B 5$ \\
\hline$X I X$ & 240 & Proceedings & 687 & $B 5$ \\
\hline$X X$ & 245 & Proceedings & 649 & B5 \\
\hline$X X I$ & 301 & Proceedings & 717 & $B 5$ \\
\hline$X X I I$ & 267 & Proceedings & 649 & $B 5$ \\
\hline XXIII & 356 & Proceedings & 797 & $B 5$ \\
\hline$X X I V$ & 386 & Proceedings & 882 & $B 5$ \\
\hline$X X V$ & 278 & Proceedings & 682 & $B 5$ \\
\hline$\sum$ & 6423 & & 15237 & \\
\hline
\end{tabular}

During the previous period, in these twenty-five professional and scientific meetings, including the Day of Preventive Medicine, 2915 papers were published in 30 different sections. In the section "Scientific Youth" 168 papers were published, which makes a total of 3083 papers. Also, twenty-five Proceedings (22 formats B5 and 3 A4 formats) were printed on a total of 15237 pages. The conference was attended by over 6423 authors and co-authors of papers and a large number of invitees, guests, journalists and interested individuals.
"Ecological Truth" was organized in 7 cities of Timok krajina and 3 cities outside Timok Krajina. The Organization was led by 12 Presidents of the Organizing Committee, while 10 prominent scientists chaired the Scientific Commmittees that took care about scientific and technical values of the Conference.

\section{INSTEAD OF THE CONCLUSION}

"Ecological Truth" is the only conference in this region, and wider, which has gathered all generations for the last twenty-five 
years, from pupils and students to professors and foreign research workers.

A large number of experts contributed to the success of the "Ecological Truth" from the Institute and from many other institutes and faculties, the Institute for Health Care in Serbia and other organizations, such as the "Society of Young Researches".

The Society of Young Researchers Bor has been one of the permanent co-organizers of the scientific-orifessional meeting "Ecological Truth" since the first conference in 1993. Since then, the co-organizers have been changed and among the large number of new co-organizers, the Society of Young Researchers Bor is the only traditional co-organizer.

A special contribution was made by the Military Medical Academy in Belgrade with its professors Mirce Obradovic and Spiro Radulovic, prof. Stevan Stankovic from the Faculty of Geography as a long-time president of the Scientific Committee, late prof. Zoran S. Markovic from the Technical Faculty in Bor and others.

In addition to scientific-professional work, special attention was paid to accompanying activities. The goal of numerous excursions was to get acquainted with the culture and natural heritage of eastern Serbia, and later Apatin, Kopaonik, Goc and Vrnjacka

\section{REFERENCES}

1. Paunovic P, Book of the Institute, ideas, achievements, experiences, possibilities, Institute for Health Protection, Timok, Zajecar;2006.

2. Häckel E., Natürliche schöpfungsgeschichte, G. Reimer, Berlin (1868).

3. Park R.E, Burgess E.W. Introduction to the Science of Sociology, Chicago ,University of Chicago Press;1921.

4. Stanković S. The framework of life - the principles of ecology, , Belgrade Nolit;1933.

5. Bulletin of the Moravian Banovina Chamber of Commerce, 3, (1939).
Banja. Participants of the event had the opportunity to get to know the beauties of the Lazarev canyon and the Zlotska cave, the Djerdap Gorge, the Bor Lake, the Moravica canyon and the thermo-mineral springs Sokobanja. Travelling by boat, they met the values of the Danube and cultural treasures of Kladovo, Apatin. They visited the first urban settlement in Europe, "Lepenski Vir", visited Rajacke pimnice, Sokograd, Jama, Vidikovac, RTB Bor, then museums in Negotin and Zajecar, the birthplace of Stevan Mokranjac and many other cultural sights.

Finally, we can say that "(Our) Ecological Truth" has great strength. Its strength is reflected in its successful living and being held every year in the 21st century.

\section{ACKNOWLEDGEMENT}

The author kindly thanks Professor Danko Nikolic for his professional help in translation of the text and Toplica Marjanovic on the statistical processing of the results in the first ten years of Ecological Truth. Special thanks go to Prof. dr Jovica Sokolovic from Technical faculty in Bor in the preparation of this paper and the analysis of the results achieved in the past 25 years of "Ecological truth".

6. Djordjevic A., The Letopis Bor Parrohi and the Church, Bor (2007).

7. Paunovic P. Ecological Meeting, The Lexicon of the health culture of Timocke Krajina, Available from: http://leksikon.zavodzajecar.rs/ index.php/e/1082016112302, Accessed on: 04 April 2018.

8. Stanojlovic R., Sokolovic J., Technologies and Sustainable Development, University of Belgrade, Technical Faculty in Bor, Bor ;2016.

9. Lazarevic M. Lies, more toxic than uranium, Timok, Zajecar ;1996.

10. Proceedings from the conference "Ecological Truth" from 1993 to $2017 ; 2017$. 